\title{
SENSORY ANALYSIS TEST OF POUNDED YAM MADE FROM A POUNDING MACHINE DESIGNED AND FABRICATED IN NIGERIA
}

\author{
Abulude F.O ${ }^{1 *}$, Elemide A.O ${ }^{2}$., Oladipupo O.K ${ }^{3}$, and Ale T.A ${ }^{3}$ \\ ${ }^{1}$ Science and Education Development Institute, Akure, Ondo State, Nigeria \\ ${ }^{2}$ Department of Agricultural and Bio-Environmental Engineering, Federal College of \\ Agriculture, Akure, Ondo State, Nigeria \\ ${ }^{3}$ Department of Agricultural Technology, Federal College of Agriculture, Akure, Ondo State, \\ Nigeria
}

*Corresponding author: walefut@gmail.com

\begin{abstract}
Pounded yam eaten with any type of soup is a delicacy eaten by Nigerians. It is manually prepared by pounding yam, cocoyam or combination with mortar and pestle. Preparation takes 30-45 mins. Researches on the improvements have taken place to reduce the heavy burden on the pounded yam preparation. One of the efforts made is the fabrication of pounding machine from the Department of Engineering, Federal College of Agriculture, Akure, Nigeria. The aim of this study is to carry out the organoleptic analysis of pounded yam produced from the fabricated machine. A ten-man panelist was used to determine the organoleptic analysis of the pounded yam in terms of the appearance, taste, colour, odour and texture. The panelists were scored with a class of quality grading: 22.6-25.0 (excellent), 20.2-22.5 (good), 18.2-20.1 (satisfactory), 16.218.1 (less satisfactory), and $<15.2$ (unsatisfactory). Also, sensory attributes were scored as $1=$ unsatisfactory, $2=1$ ess satisfactory, $3=$ satisfactory, $4=$ good, and $5=$ excellent. The results were statistically analysed. From the results it was found that the mean results of appearance, colour, odour, taste, and texture were $4.55,4.43,4.15,4.32$, and 4.08 respectively. Coefficients of variation (\%) were $16.89,17.80,21.65,15.67$, and 24.40 . The Skewness of the parameters was in negative, while only odour has its Kurtosis in negative form $(-0.37)$. All the panelists rated the appearance (19-24\%) of all the samples high above all other parameters. The Pearson Coefficient of Correlation and Principal Component Analysis showed elements of relationships between the parameters. In conclusion, the machine pounded yam was scored above satisfactory, which means the fabricated machine was efficient.
\end{abstract}

Keywords: Pounded yam, cocoyam, machine, panelist, texture, Yorubas, Nigeria

\section{INTRODUCTION}

Africans are blessed with local foods, Nigeria one of the countries therein is likewise blessed with different types of local foods. One of the local foods is pounded yam, a very popular delicacy (Olaoye and Oyewole, 2012). Pounded yam is eaten with different soups like vegetable, ogbono, okro, egunsi soups. Most occasions and parties in Nigeria, especially the Yorubas serve pounded yam as the menu. Pounded yam is usually made from yam, cocoyam or the mixtures and pound with mortar and pestle.

Yam an ingredient of pounded yam is a member of the genus Dioscorea is an important staple food in West Africa (Ekwu et al., 2005). It is grown annually and perennially in Africa, the Americas, the Caribbean, South Pacific and Asia. It is indigenous to West Africa (IITA, 2018). 
The common species available are the Yellow yam (D. cayenensis), Water yam (D. alata), D. rotundata, and D. esculenta. According to FAO (1989), yam has great prospect of contributing to closing the projected food deficit in Africa in the 21 st century. Out of the $94 \%$ of West African's production, Nigeria single handedly produce $71 \%$, making a total of more than 37 million tons (IITA, 2018). In Nigeria, February and April tubers are planted and are harvested between 180 to 270 days. Nutritionally, yam tubers consist of about $21 \%$ dietary fiber and are rich in carbohydrates, vitamin $\mathrm{C}$ and essential minerals. Yams are processed into less perishable products through a drying process to make flour (Jimoh and Olatidoye, 2009).

\section{Cocoyam}

Cocoyams are perennial plants, which belongs to the family Araceae. This root and vegetable crop are edible (Deni, 2000). Cocoyams which are planted as food crops belong to either the genus Colocasia or the genus Xanthosoma and are made of a large spherical corm, from which a few large leaves emerge. Colocasia species may also be referred to as taro and originates from Southeast or Central Asia (Rao et al., 2010). Cocoyam has high nutritional values (vitamins, minerals, and protein) when compared with cassava and yam. It can be consumed in different ways by roasting, cooking, frying, baking, pounding and milling. Colocasia species are known to have health benefits like reduction in the symptoms of rheumatoid arthritis, prevents cancer, reduces blood pressure, plays important in the immune system, reduces cramps, boots vision, and enhances learning (Admin, 2016).

Pounded yam production is a tedious process, which is carried out by pounding cooked slices of yam in a mortar using a pestle to a smooth dough consistency (Oluwamukomi and Adeyemi, 2015). However, instant pounded yam flour, which is a modern invention to simplify the tedious traditional process. There are has been a lot of improvements in the processing of pounded yam to eliminate the tedious process. For example, poundo yam flour has been developed, this is just a fortified flour, which is stirred in a pot within 5-10 min, it is ready to be served (Oluwamukomi and Adeyemi, 2015; Ayodeji et al., 2014; Olaoye and Oyewole, 2012; Adeola et al., 2012). Also, is the design and fabrication of machines which are used in the production of pounded yam (Adebayo et al., 2014; Ikechukwu and Munch, 2015). However, these and some others failed due to some limitations like poor pounding, a limited quantity of pounded yam production, stirrer or mixer problems, and production of excessive heat during usage just to mention a few. It is on this premise, the pounding machine used in the study was designed and fabricated to correct the limitations. Part of the evaluation is the organoleptic analysis of the pounded yam produced from the machine. This study evaluated the acceptability, taste, odour, colour, and texture using a ten man panelist.

\section{MATERIALS AND METHODS}

The tubers of white yam (Dioscorea alata) and corms of white cocoyam (Colocasia esculenta) varieties, the gas cooker, pestle and mortar used for this work were procured from the Oja Oba market in Akure, Ondo State, Nigeria.

\section{Design and Fabrication of Machine}

The design and fabrication were carried out in the workshop of the Department of Agricultural and Bio-Environmental Engineering, Federal College of Agriculture, Akure, Ondo State, Nigeria, and have been reported elsewhere (Ogunlade, 2015). 


\section{Preparation of Yam tuber and corms of cocoyam for pounding}

Machine (Fig 1)

1. Cocoyam only pounded with mortar and pestle $-910 \mathrm{~g}$ (Control)

2. Yam only pounded with mortar and pestle $-910 \mathrm{~g}$ (Control)

3. A mixture of yam $(637 \mathrm{~g})$ and cocoyam $(273 \mathrm{~g})$ - Ratio $3: 1$

4. A mixture of yam $(455 \mathrm{~g})$ and cocoyam $(455 \mathrm{~g})$ - Ratio $1: 1$

5. Cocoyam only pounded with the machine $-910 \mathrm{~g}$

6. Yam only pounded with the machine $-910 \mathrm{~g}$

\section{Control}

Same quantities were used in the preparations, but mortar and pestles were employed (Fig 2)

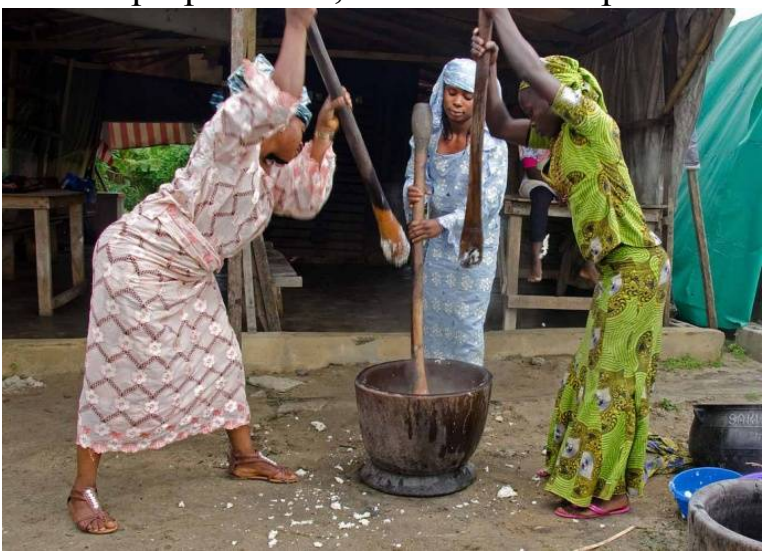

Fig 2. Pounded yam made of mortar and pestle

\section{Measurements (Time and volumes)}

The volume of water used for cooking $-500 \mathrm{~cm}^{3}$ (Enough to cover the yam and cocoyam)

Time of cooking - $12 \mathrm{~min}$ (The yam and cocoyam were cut into small pieces).

Time of pounding (Machine) - 3mins

Time of pounding (Control) - 10 mins

\section{Production of Pounded Yam}

\section{Cooking of yam}

The brown outer layer tubers and combs were peeled, sliced and washed the white part with lots of clean water, transferred into cooking pots and cooked with water. Cooked for twelve minutes, and then checked with a kitchen fork by piercing to see if the yams were soft enough for the pounding. Once the yams were soft enough for pounding then it was ready for the pounding part. The water was not completely dried because it was needed for pounding the yam in the mortar and pestle. The flow chart for the pounding is shown in Figure 3.

\section{Pounded yam and Cocoyam preparations}

The cooked yam was transferred into the machine, covered and switched on. The rotor of the machine was rotated for 3 minutes. After this period, the pounded yam ready, packed in a clean plate, preserved hot, and then served to the panelists. Same procedure for pounding was used for the control, but this time, a pestle and mortal replaced the fabricated machine until the yam was seedless and can easily be molded (20 minutes). 


\section{Note}

The yam used for the project has stayed for over three months before use. New yam may not be suitable for pounding.

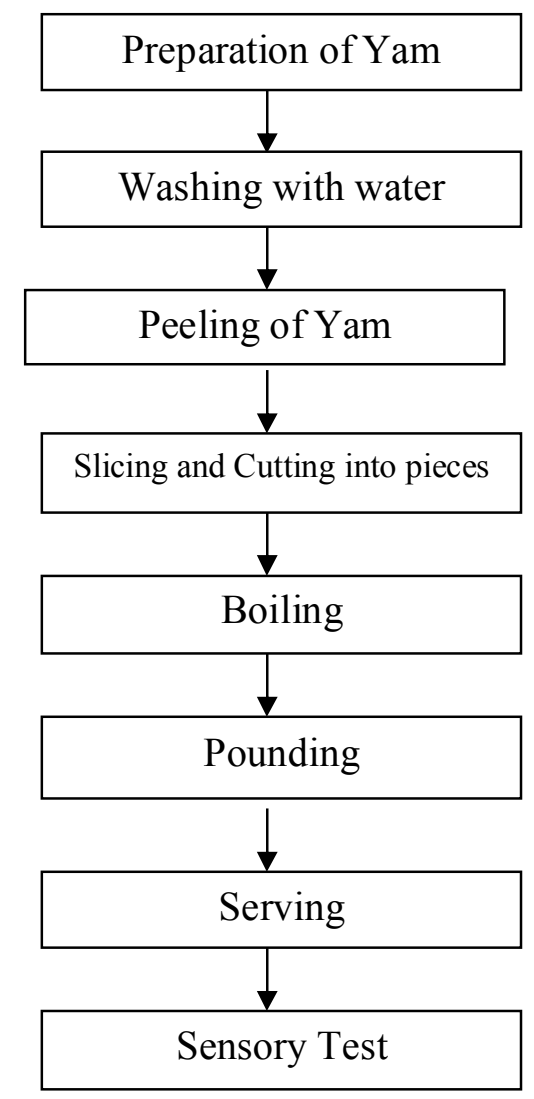

Fig 3: Flow Chart of the Production of Pounded Yam

\section{Sensory Evaluation}

The pounded yam made from yam, cocoyam and the mixtures of the yam and cocoyam were compared. Two different groups of (10 members; 5 men and 5 women) consumer type untrained sensory panelists were selected from students of Federal College of Agriculture, Akure, Ondo State. They were briefly trained in the methodologies involved.

Each panelist was provided with a separate score sheet. Water was provided to rinse the palate between two tasting sessions. Also, quality attributes, colour, texture, taste, appearance, and odour were evaluated. The class of quality grading: 22.6-25.0 (excellent), 20.2-22.5 (good), 18.220.1 (satisfactory), 16.2-18.1 (less satisfactory), and $<15.2$ (unsatisfactory). Also, sensory attributes were scored as $1=$ unsatisfactory, $2=$ less satisfactory, $3=$ satisfactory, $4=$ good, and $5=$ excellent. 


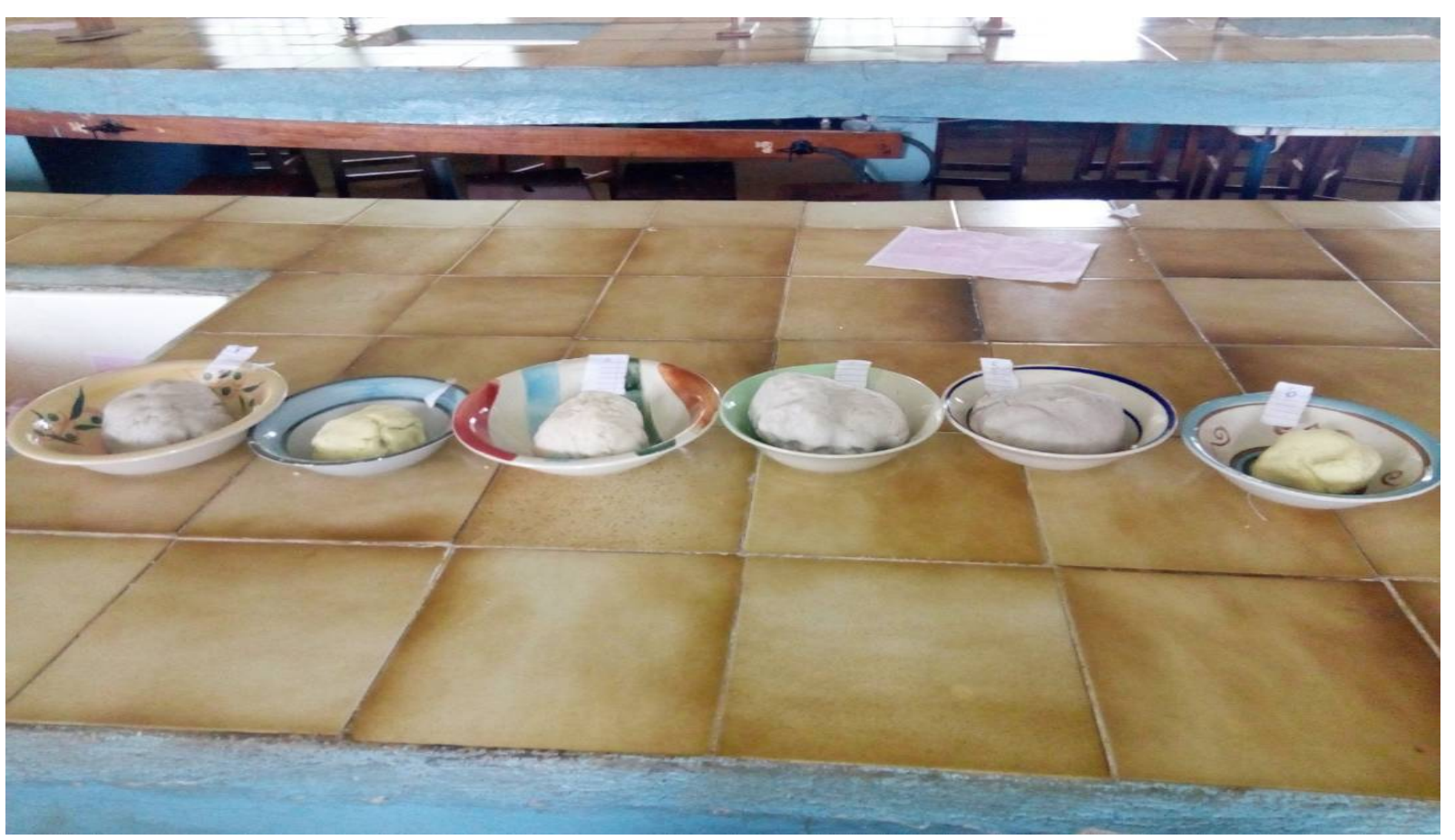

Fig 4. Samples of Pounded Yam produced by the fabricated machine and control

Statistically, the results obtained in the study were analysed using Minitab 18 (Descriptive statistical, correlation coefficient, and matrix) and Excel (charts).

\section{RESULTS AND DISCUSSION}

Table 1 depicted the descriptive statistical results of the organoleptic tests of the pounded yam samples. From the results, it was found that the mean results of appearance, colour, odour, taste, and texture were $4.55,4.43,4.15,4.32$, and 4.08 respectively. Coefficients of variation (\%) were $16.89,17.80,21.65,15.67$, and 24.40 the indication of these values showed little margins (variations) in the decisions of the panelists. It could be deduced that all the samples products accepted by the panelists. These results were in agreement with those previously reported (Akissoe et al., 2009; Adeola et al., 2012). The Skewness of the parameters was in negative. This showed that in the distributions, the mean is less than the median, which is always less than the mode. The opposite is the case if it were to be positively distributed. If a normal distribution is skewed it has either of its tails longer than the other. Since the distributions are negatively skewed it means they have long tails in the negative directions. Only odour has its Kurtosis in negative form (-0.37). Since this value is less than 0 , it is considered to be a "light-tailed". Kurtosis as it is known is measured against the normal distribution. When the kurtosis is close to 0 , then a normal distribution is often assumed (mesokurtic distributions), but when it is less than 0 , then the distribution is light tails (platykurtic distribution). If the kurtosis is greater than zero, then the distribution has heavier tails and is called a leptokurtic distribution (McNeese, 2016).

The individual score of the panelists depicted in Fig 5 showed that panelists 5 and 6 rated nearly all the products (1-6) excellent, except the colour and texture which they rated good. Products 5 (Cocoyam only pounded by machine) and 6 (Yam only pounded by machine) were accepted by the panelists. The fabricated machine could have improved the sensory quality of the pounded 
yam. Figure 6, showed the contributions of each organoleptic parameter in the samples. All the panelists rated the appearance (19-24\%) of all the samples high above all other parameters. The appearance was not affected by stain from the machine and mortar and pestle, there were no signs of unmashed yam or dirt which could have altered the appearance. The excellent appearance in the samples would assist in the marketing and choice. Colour contributed between $19-22 \%$, the reasons for the differences were due to panelists' taster status and their different opinions (perceived colour differently). Likewise, the odour was scored between 12 and 24\%. Odour can be an appetizer in food intake and an important characteristic of food, which influences food choice behaviour. The odour recorded by the panelist showed that the pounded yam obtained using the machine was satisfactory. The results obtained in his study compared with a commercial poundo yam produced by Adeola et al., (2012); "poundmix" (Oladeji and Akanji, 2011); pounded yam (Akissoe et al., 2009), "foutou" (Nindjin et al., 2007); pounded yam (Otegbayo et al., 2007) in terms of the sensory attributes.

The Pearson correlation coefficient analysis of the organoleptic parameters determined are shown in Table 3. This table presented the overview of the correlations. There were significant correlations between odour and colour $(\mathrm{R}=0.46)$, Taste and odour $(\mathrm{R}=0.51)$, texture and odour $(\mathrm{R}=0.52)$, and texture and taste $(\mathrm{R}=054)$. The correlation between odour and colour were a weak correlation, were strong correlations. It implied that it is all the organoleptic parameters used in the test gave a good account of the pounded yam samples from both the control and test (machine). Baah et al. (2009) and Oluwamukomi and Adeyemi (2015) evaluated the quality of pounded yam and composite of poundo yam respectively. The results of the evaluations were similar to ours. The tastes, aroma, the colour of the samples were preferred by the panelists. Fig 7 showed the matrix plot of the results. The plot explained the relationships in appearance, colour, odour, taste, and texture of the samples. The organoleptic tests were in diagonal line with each variable plotted against each other at the top and down (forming mirror image). Where the scatterplot looks alike, it shows a correlation. From the table, it showed that there were relationships between texture, taste and odour; taste and odour, and colour and odour. The Pearson correlation coefficient in Table 2 confirmed this.

The Principal Component Analysis (PCA) and loadings results are shown in Table 3. The number of principal components (PC) was determined by the size of the eigenvalue greater than 0.5. The PC1 component was strongly correlated with odour and taste. This showed that there was a relationship with odour and taste. The second (PC2) correlation was appearance and colour having -0.705 and 0.654 respectively. In the result the percentages of the total variance of PC1 was $48.1 \%$, PC2 accounted for $66.1 \%$, and PC3 had $82.8 \%$. In the loading plot (Fig 8), the organoleptic parameters were all clustered together and they were far from the origin, which showed that they were correlated. Odour, texture, and taste were closer than any other parameter, indicating a higher correlation this was evident in Table 3. 
Table 1. Descriptive Statistical results of organoleptic analysis test Appearance Colour Odour Taste Texture

\begin{tabular}{lrrrrr}
\hline Mean & 4.55 & 4.43 & 4.15 & 4.32 & 4.08 \\
SE Mean & 0.10 & 0.10 & 0.12 & 0.09 & 0.13 \\
Std Deviation & 0.77 & 0.79 & 0.90 & 0.68 & 1.00 \\
Coef Variation (\%) & 16.89 & 17.80 & 21.65 & 15.67 & 24.40 \\
Minimum & 1.00 & 1.00 & 2.00 & 2.00 & 1.00 \\
Maximum & 5.00 & 5.00 & 4.00 & 4.00 & 4.00 \\
Skewness & -2.49 & -2.02 & -0.74 & -0.82 & -0.92 \\
Kurtosis & 8.14 & 8.14 & -0.37 & 1.02 & 0.30 \\
\hline
\end{tabular}

Table 2. Pearson Correlation Coefficient of the test results (P-Value)

\begin{tabular}{lcclll}
\hline & Appearance & Colour & Odour & Taste & Texture \\
\hline Appearance & 1 & & & & \\
Colour & 0.131 & 1 & & & \\
Odour & 0.271 & $\mathbf{0 . 4 5 7}$ & 1 & & \\
Taste & 0.214 & 0.310 & $\mathbf{0 . 5 0 6}$ & 1 & \\
Texture & 0.227 & 0.169 & $\mathbf{0 . 5 1 6}$ & $\mathbf{0 . 5 3 9}$ & 1 \\
\hline \multicolumn{1}{c}{$\mathrm{P}<0.05$} & & & & & \\
\hline
\end{tabular}

$\mathrm{P}<0.05$

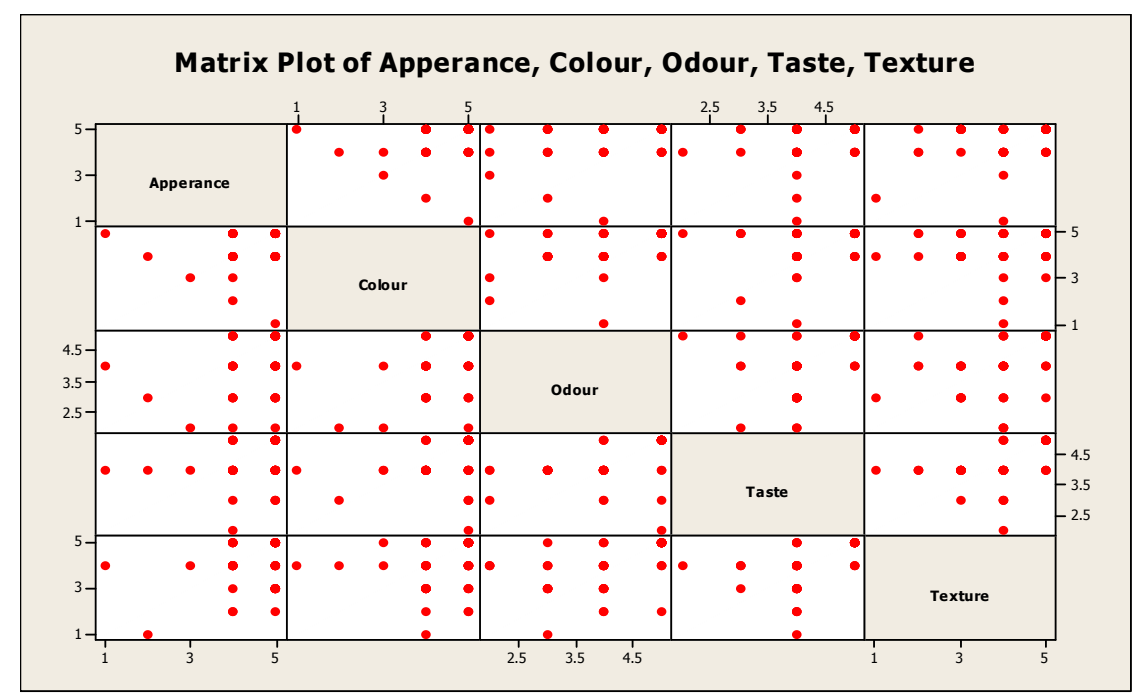

Fig 7. Matrix plot of the rest results 
Table 3. Principal Component Analysis loading factor of the results

\begin{tabular}{lccccc}
\hline Variable & PC1 & PC2 & PC3 & PC4 & PC5 \\
\hline Appearance & 0.293 & -0.705 & -0.638 & 0.082 & 0.053 \\
Colour & 0.371 & 0654 & -0.507 & 0.080 & 0.414 \\
Odour & 0.537 & 0.146 & -0.034 & -0.512 & -0.654 \\
Taste & 0.505 & -0.003 & 0.318 & 0.775 & -0.209 \\
Texture & 0.483 & -0.233 & 0.483 & -0.353 & 0.595 \\
Eigen value & 2.405 & 0.898 & 0.848 & 0.475 & 0.382 \\
Proportion & 0.481 & 0.180 & 0.168 & 0.095 & 0.076 \\
Cumulative & 0.481 & 0.661 & 0.829 & 0.924 & 1.000 \\
\hline
\end{tabular}

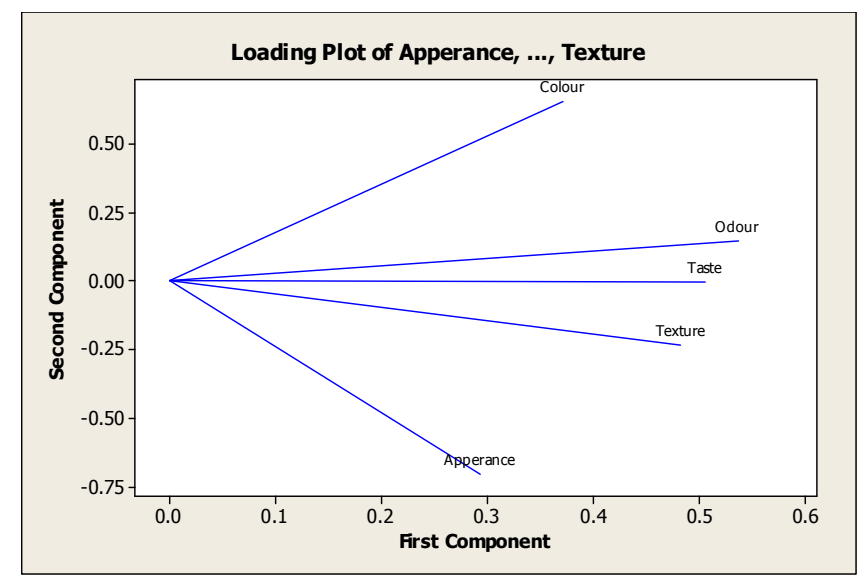

Fig 8. Loading plot of the organoleptic results

\section{CONCLUSION}

The organoleptic analysis was performed on the control (pounded yam from mortar and pestle) and test samples (Pounded yam from the fabricated machine) of pounded yam, cocoyam and the mixtures of both. The study revealed that all the samples were accepted by the panelists. The results revealed too, that the appearance of the pounded yam and cocoyam samples only made from the fabricated machine and the control was scored excellent. In conclusion, the fabricated machine's efficiency was high.

\section{REFERENCES}

1. Adebayo A.A., Yusuf K.A., and Oladipo A (2014). Fabrication and Performance Evaluation of a Yam Pounder Cum Boiler. Scientia Agriculturae. 8 (3), 2014: 112-120.

2. Adeola A.A, Otegbayo B.O., and Ogunnoiki (2012), Preliminary Studies on the Development and Evaluation of Instant Pounded Yam from Dioscorea alata. J. Appl. Sci. Environ. Manage. Vol. 16 (3) $287-290$.

3. Adigun E.T (2015). Testing and Renovation of yam pounding machine. Department of Agricultural Technology, Federal College of Agriculture, Akure, Ondo State. ND Project. Unpublished. 
4. Admin (2016). The nutritional and health benefits of cocoyam. Food and nutrition. Pharmanews. https://www.pharmanewsonline.com/8216-2/.

5. Akissoe N, Mestres C, Hounhouigan J., and Nago M (2009). Sensory and Physicochemical Quality of Pounded Yam: Varietal and Storage Effects. Journal of Food Processing and Preservation 33: 75-90.

6. Ayodeji S.P., Olabanji O.M., and Akinnuli B.O (2014). Development and Performance Evaluation of a Sieving Machine for Poundo Yam Process Plant. Journal of Emerging Trends in Engineering and Applied Sciences (JETEAS) 5(4): 229-236.

7. Baah F.D, Maziya-Dixon B, Asiedu R, Oduro I and Ellis W.O (2009). Physicochemical and pasting characterisation of water yam (Dioscorea spp.) and relationship with eating quality of pounded yam. Journal of Food, Agriculture \& Environment. Vol.7 (2) : 107 - 112 ..

8. Babatunde Oladeji, Cahales Taiwo Akanbi, (2011) "Physico-chemical and sensory evaluation of "poundmix" from yam, cocoyam, breadfruit and plantain blends", Nutrition \& Food Science, Vol. 41 Issue: 436, https://doi.org/10.1108/00346651111181985.

9. Deni Bown (2000). Aroids: Plants of the Arum Family. Timber Press, Portland

10. Ekwu F.C, Ozo N.O, Ikegwu O.J, (2005). Quality of fufu form white yam varieties (Dioscorea spp). Nigerian Food Journal 23:107-113.

11. FAO (1989). Roots, Tubers, and Plantains in Food Security: In Sub-Saharan Africa, in Latin America and the Caribbean, in the Pacific". FAO. 1989. ISBN 978-92-5-102782-0.

12. IITA (2018). Yam (Dioscorea species). http://www.iita.org/crops/dioscoria/. Accessed $1^{\text {st }}$ October, 2018.

13. Ikechukwu G.A and Munch M.J (2015). Development of a Motorized Yam Pounding Machine Design to Improve Standard of Living for Sustainable Economic Development in Nigeria. Proceedings of the World Congress on Engineering 2015 Vol II. WCE 2015, July 1 3, 2015, London, U.K.

14. Jimoh, K.O. and Olatidoye O.P., (2009). Evaluation of physicochemical and rheological characteristics of soybean fortified yam flour. Journal of Applied Biosciences 13:703-706.

15. McNeese B (2016). Are the Skewness and Kurtosis Useful Statistics? https://www.spcforexcel.com/knowledge/basic-statistics/are-skewness-and-kurtosis-usefulstatistics. Updated, February 2016.

16. Nindjin C., Otokore D., Hauser S., Tschannen A, Farah Z., and Girardin O (2007). Determination of relevant sensory properties of pounded yams (Dioscorea spp.) using a 
locally based descriptive analysis methodology. Food Quality and Preference. Volume 18, Issue 2, Pages 450-459.

17. Olaoye, J. O., and S. N. Oyewole. (2012). Optimization of some "poundo" yam production parameters. Agric Eng Int: CIGR Journal, 14(2):58-67.

18. Oluwamukomi M.O and Adeyemi A.O (2015). Physico-Chemical, Pasting, and Sensory Properties of "Poundo"-Yam Enriched with Defatted Soy Flour. Applied Tropical Agriculture. Volume 20 (1): 89-95.

19. Otegbayo, B., Aina, J., Abbey, L., Sakyi-Dawson, E., Bokanga, M. \& Asiedu, R. (2007). Texture profile analysis applied to pounded yam. Journal of Texture Studies, 38(3), 355-372.

20. Rao V. R., Matthews P.J, Eyzaguirre P.B and Hunter D (eds) (2010). The Global Diversity of Taro: Ethnobotany and Conservation. Rome, Bioversity International. 


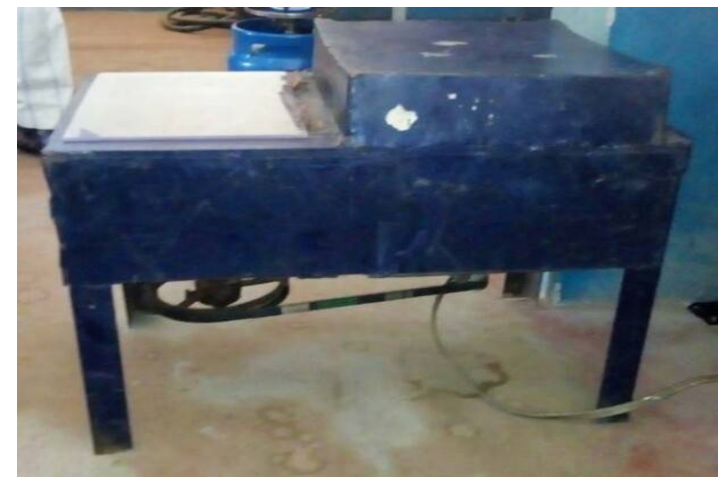

Right View

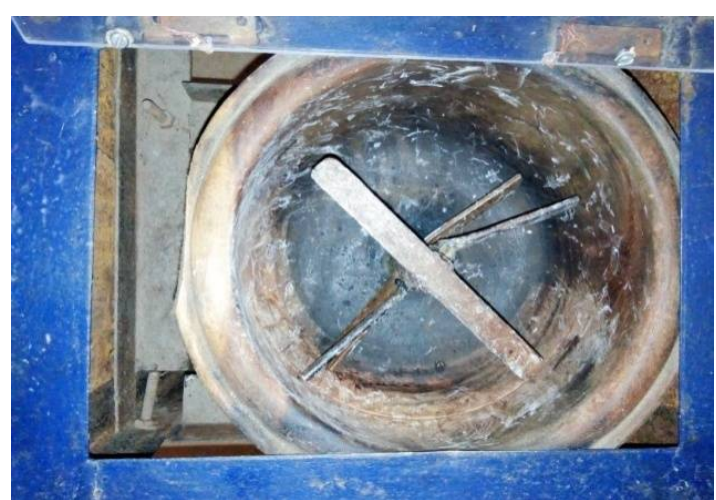

Top View with without Cover

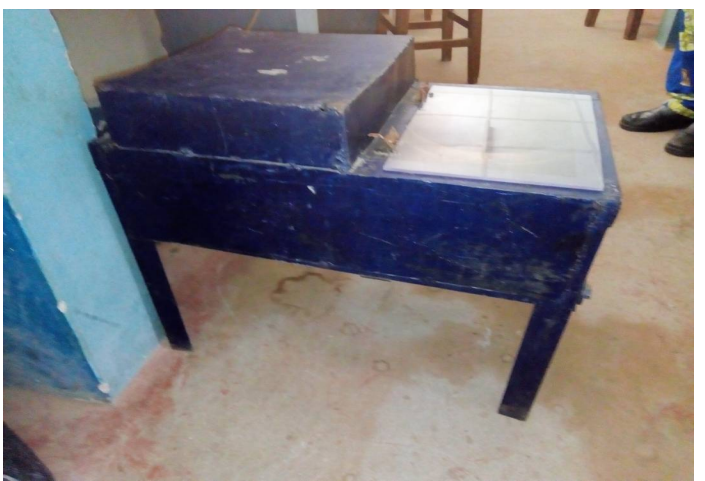

Left View

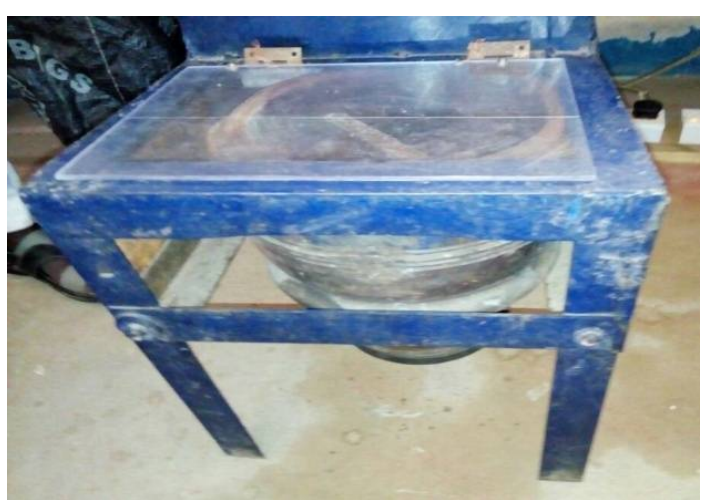

Front View

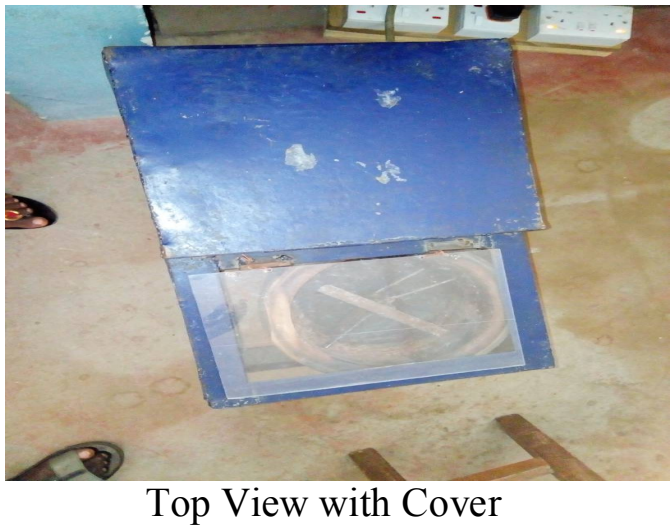

Top View with Cover

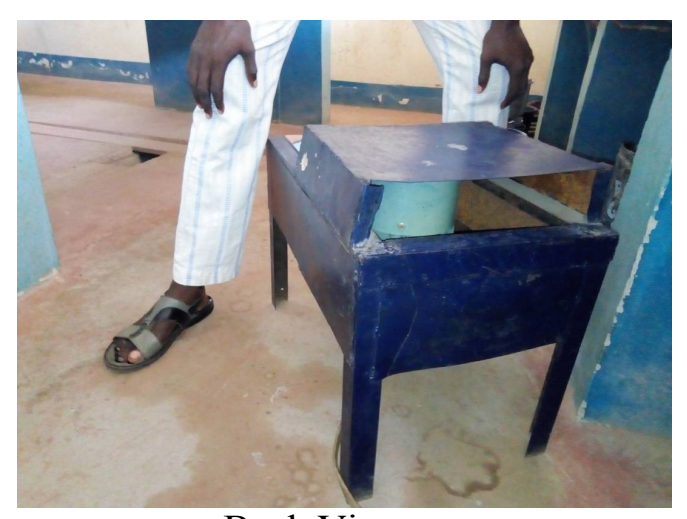

Back View

Fig 1. Photographs of the fabricated machine used for the production of pounded yam 

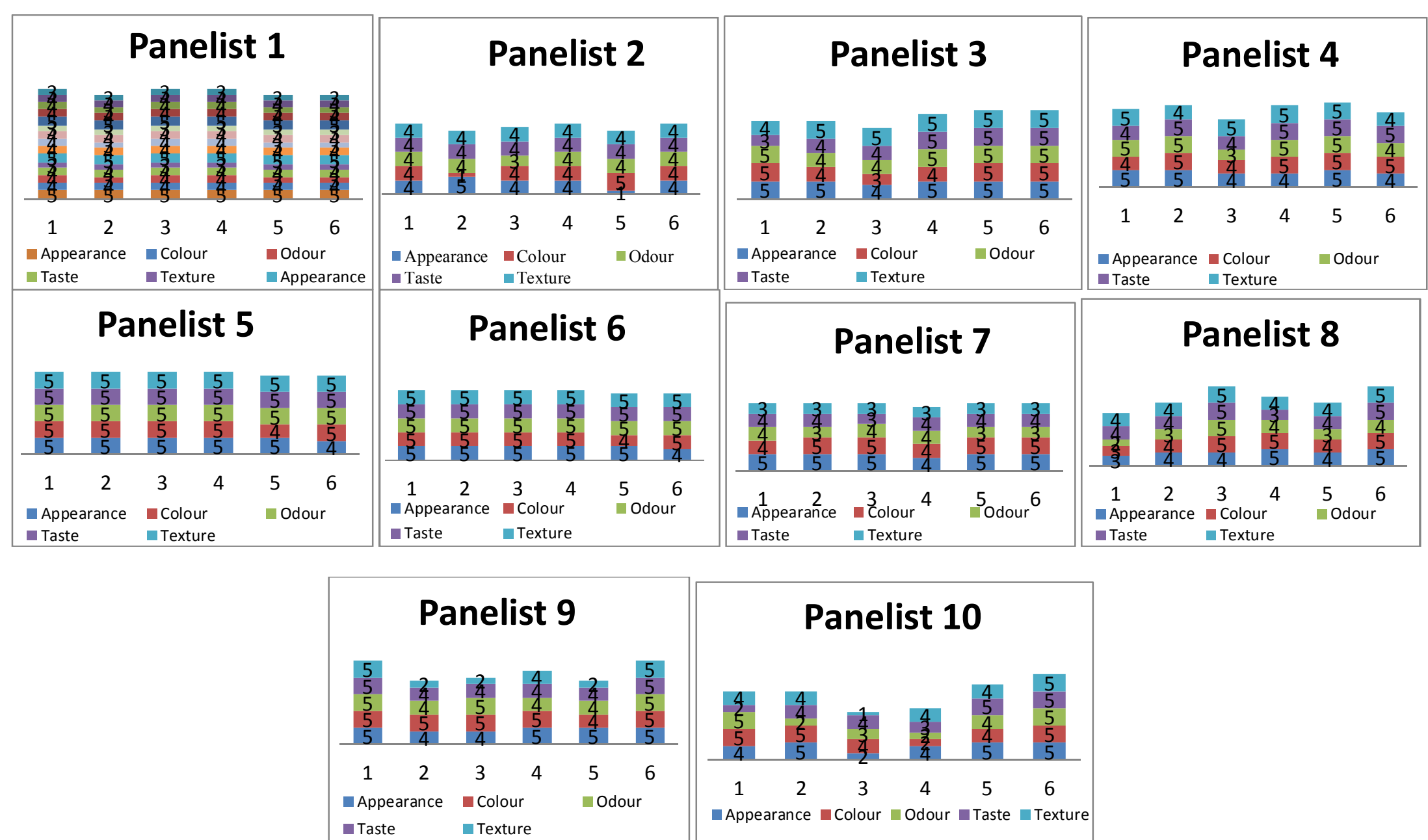

(1)- Cocoyam only pounded with mortar and pestle (Control) (2) - Yam only pounded with mortar and pestle (Control) (3) - Mixture of yam and cocoyam (Ratio 3:1). (4) - Mixture of yam and cocoyam (Ratio 1:1). (5)- Cocoyam only pounded with machine (6) - Yam only pounded with machine

Fig 5. The ratings of the samples by individual panelists (1-10) 

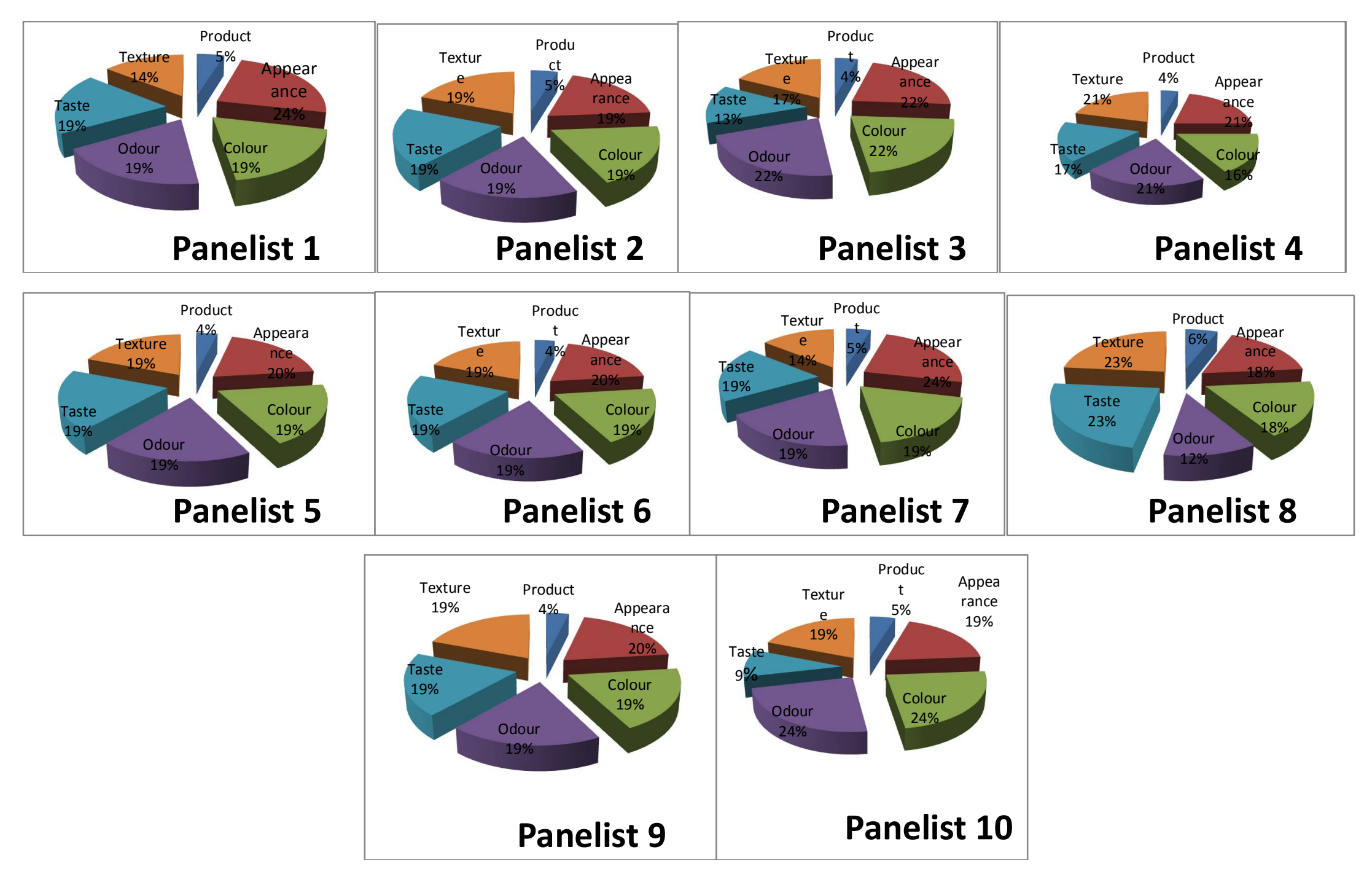

Fig 6. The contributions of each organoleptic parameter in the samples. 